\title{
Relationship Between Teacher's Content Knowledge, Pedagogical Content Knowledge, and Self-Efficacy and Its Impact on Student's Mathematics Learning Achievement
}

\author{
I Gusti Putu Suharta* \\ Department of Mathematics Education \\ Universitas Pendidikan Ganesha \\ Bali, Indonesia \\ *putu.suharta@undiksha.ac.id
}

\author{
Ni Nyoman Parwati \\ Department of Mathematics Education \\ Universitas Pendidikan Ganesha \\ Bali, Indonesia \\ nyoman.parwati@undiksha.ac.id
}

\begin{abstract}
Teacher's content knowledge (CK), pedagogic content knowledge (PCK), and self-efficacy (SE) are factors that can affect the effectiveness of learning process. This study aims to determine the relationship between $\mathrm{CK}, \mathrm{PCK}$, and SE and their impact on students' mathematics learning achievement. This type of research is ex post facto, with the variables are mathematics teachers and junior high school students in Buleleng regency. Teacher samples were taken by using area cluster random sampling, while the student samples were determined by technique purposive sampling. The instrument used to measure CK, PCK, and mathematics learning achievement was a test, while the SE was measured by a questionnaire. Furthermore, the data were analysed inductively using Path Analysis. The results showed that both of CK and PCK had positive relationship with student's mathematics learning achievement, both directly and indirectly. However, SE had no significant relationship with students' mathematics learning achievement.
\end{abstract}

Keywords: content knowledge, pedagogical content knowledge, self-efficacy, learning achievement

\section{INTRODUCTION}

Content knowledge $(\mathrm{CK})$ is the teacher's understanding of the material, whereas pedagogical content knowledge (PCK) is the teacher's knowledge about learning and how students learn. The previous research conducted in elementary school teachers in Turkey showed that there was a significant relationship between $\mathrm{CK}$ and PCK, and these two types of knowledge are important in the study of mathematics [1]. In addition, $\mathrm{CK}$ has a high relationship with self-efficacy and effective learning, while PCK has a high relationship with effective learning [2].

Mathematics self-efficacy can be function as a predictor of the self-efficacy of teachers in mathematics [3]. Previous researchers found that there was a very strong relationship between teacher's self-efficacy and mathematics learning achievement of secondary level students [4,5]. Besides, students' self-efficacy also have a positive relationship with the understanding of the fractions concept [6].

Components of teacher's knowledge of mathematics is the mathematical knowledge, mathematical representations of knowledge, knowledge of students, learning knowledge, and make a decision [7]. The teacher's knowledge domain for teaching mathematics consists of subject matter knowledge and pedagogical content knowledge. Subject matter knowledge consists of general material knowledge, specific material knowledge, and horizon material knowledge, while pedagogical content knowledge consists of material and curriculum knowledge, material and student knowledge, and material and learning knowledge [8]. Based on the two opinions, the teacher's knowledge to teach mathematics in the form of material knowledge and pedagogic material knowledge. Material knowledge or what is often called CK is general material knowledge, specific material needed related to certain learning, and also knowledge related to material in the next class. Pedagogic material knowledge is often called the PCK is teachers knowledge about the curriculum in force, knowledge of how students learn and think mathematics, as well as how to teach the material so that students can understand.

Components of PCK is (1) the conception of the purpose of learning, knowledge and confidence learning objectives, (2) knowledge of students including student understanding, conceptions and misconceptions of a material, (3) curricular knowledge, and (4) knowledge of learning strategies [9]. The development of PCK components between experts showed inconsistency. However, from various points of view the component of knowledge about students is emphasized, including concept errors made by students. Therefore, assessment of teachers PCK concerned with understanding of misconceptions, understand the reasons students misconceptions, be creative solution to change the misconceptions students, and ask the right questions to fix upset a concept of students. 
Frame work and cognitive tools have been developed to improve the PCK teachers [10]. Previous researches have explored the potential of science teaching cases to deepen $\mathrm{CK}$ and PCK teachers [11] and compared PCK mathematics teachers in the US and Chinese secondary schools [12]. Other researchers examined the reflective practices of two preservice teachers during their students' teaching internships and found limitations in PCK and lack of trust that hindered teacher service reflection while teaching [13].

Some researches also focused on examination of the CK and PCK of elementary school teacher candidates on decimal numbers. They asked the prospective teachers to complete decimal ratio, marking section which allegedly difficult for students, and shortly explain why. Results of the study showed the need for teacher training to emphasize CK integrated with different aspects of the amount of knowledge and PCK which includes a thorough understanding of the general difficulty [14]. Other studies identified influences on the subject matter knowledge of "subject teachers" to teach the pedagogical reasoning process. Their findings indicate that the four teacher candidates in Indonesia differ in their subject matter knowledge to teach both in different aspects of the concepts they emphasize and in the use of representations to structure learning activities [15].

Self-efficacy is defined as a person's belief in its capacity to manage and implement actions to achieve the goals set, and trying to assess the extent and strength of all the activities and context [16]. The teacher's self-efficacy of mathematics learning is interpreted as the teacher's self-confidence in his ability to plan, implement, and assess to be effective in the classroom and achieve the expected competencies. This selfefficacy will provide a strong impetus for optimal learning so that effective learning is developed. Teachers who have a selfefficacy well then the teacher can implement effective learning and can affect student achievement [17]. Results of other studies showed that it is teacher's self-efficacy affects student performance, student attitudes toward learning, and student growth [18]. Regarding the relationship between CK and PCK knowledge of secondary school teachers, it was found that there was a very strong relationship with student achievement [19].

Content knowledge of mathematics and pedagogy content knowledge is an integral part of an effective mathematics teaching [20]. To build mathematical concepts in students' minds, content pedagogic knowledge, as well as content knowledge of mathematical is needed. The way teachers relate subject matter to pedagogical knowledge and how knowledge of mathematical content is part of the pedagogical reasoning process is seen as the integration of pedagogical content knowledge [1]. This teacher's behaviour will colour the teacher's PCK that have an impact on student achievement.

The results of the elaboration described above, have shown that there is a very strong relationship between CK, PCK, and teacher's self-efficacy (SE) with student achievement. However, the previous results have not shown the relationship between CK, PCK, and SE, and its effect on student achievement. Therefore, in this recent study, we investigated the relationship between $\mathrm{CK}, \mathrm{PCK}$ and SE and its impact on student achievement.

\section{RESEARCH METHODS}

This research used ex post facto design. The research populations were all mathematics teachers who are teaching at grade VIII and students of grade VIII at public Junior High School in Buleleng Regency. The school sample was determined by the cluster random sampling technique, while the samples of teachers and students were determined purposively by considering the school sample. The samples were 8 teachers and 266 students that were distributed into 8 schools in Buleleng Regency.

The instrument used to measure CK, PCK, and student achievement was a test, while the instrument used to measure the SE was a questionnaire. CK test was developed with reference to the material that was taught in the 1st semester and was taken from the enrichment problems exist in the Book of Teachers of Mathematics Junior high school of grade VIII [21]. The material consists of coordinate systems, algebraic operations, functions, straight-line equations, Pythagoras theorem, and statistics. The number of question for each topic were one question, so the teacher $\mathrm{CK}$ test was 6 questions. CK was observed by using indicators that use concepts to solve mathematical problems that are enriching as well as the ability to see other concepts that are related to problem solving.

PCK was measured through mathematical problem solving in class. Se each issue is fundamentally focused on the interpretation of the teacher on a misconception of the students or the misunderstanding of mathematical knowledge. In general, the expectations of the teacher are; understand conception / reasoning of students, understand the rationale or student reasoning, creating a solution for improve reasoning one of the students, can ask the right questions to understand the thinking of students, as well as ask questions to improve students' reasoning or understanding concepts [1].

Mathematics learning achievement is the student's ability to solve problems related material coordinate system and operation algebraic tests collected by objective form with reference to the basic competence and indicator. SE questionnaire was developed by referring to the belief in the implementation of learning and accommodating a questionnaire developed by Lisa Etheridge with many items being 21 [3]. Furthermore, all data on the change to the scale of 100 . For hypothesis testing, data are analysed inductively using Path Analysis.

\section{RESULTS AND DISCUSSION}

The null hypothesis formulation related to the research hypothesis is "there is no relationship between CK, PCK, SE and the impact on student's mathematics learning achievement". To test the null hypothesis the significance level of $5 \%$ is used. It has meaning that if the significant value in the table is less than or equal to 0.05 , meaning null hypothesis is rejected, and if the significance value in the table 
TABLE V. MOdEl SUMmary Path ANAlysis

is more than 0.05 it means that the null hypothesis is accepted. A summary of the path analysis is shown in the table 1 .

TABLE I. SUMMARY PATH ANALYSIS MODEL

\begin{tabular}{|c|c|c|c|c|}
\hline Model & $\mathbf{R}$ & $\begin{array}{c}\mathbf{R} \\
\text { Square }\end{array}$ & $\begin{array}{c}\text { Adjusted R } \\
\text { Square }\end{array}$ & $\begin{array}{c}\text { Std. Error of the } \\
\text { Estimate }\end{array}$ \\
\hline 1 & $.965^{\mathrm{a}}$ & .931 & .903 & 4.35349 \\
\hline
\end{tabular}

TABLE II. COEFFICIENTS ${ }^{\mathrm{A}}$ PATH ANALYSIS

\begin{tabular}{|c|c|c|c|c|c|c|}
\hline \multirow{2}{*}{\multicolumn{2}{|c|}{ Model }} & \multicolumn{2}{|c|}{$\begin{array}{l}\text { Unstandardized } \\
\text { Coefficients }\end{array}$} & \multirow{2}{*}{$\begin{array}{c}\begin{array}{c}\text { Standard } \\
\text { ized } \\
\text { Coefficie } \\
\text { nts }\end{array} \\
\text { Beta }\end{array}$} & \multirow[t]{2}{*}{$\mathbf{t}$} & \multirow[t]{2}{*}{ Sig. } \\
\hline & & $B$ & $\begin{array}{c}\text { Std. } \\
\text { Error }\end{array}$ & & & \\
\hline \multirow[t]{3}{*}{1} & (Constant) & -73.620 & 18.262 & & -4.031 & .010 \\
\hline & CK (X1) & .791 & .119 & .786 & 6,636 & .001 \\
\hline & SE (X3) & 1.083 & .194 & 661 & 5.574 & .003 \\
\hline
\end{tabular}

Based on table 2, the significance of X1 is 0.001 and $\mathrm{X} 3$ is 0.003 , both of which are less than 0.05 . This means that at the $5 \%$ significance level, $\mathrm{X} 1$ and $\mathrm{X} 3$ have contributed to $\mathrm{X} 2$ with beta values of 0.786 and 0.661 . Based on table 1 , the error (e) can be calculated from SQRT $(1-0.931)=0.26$. Analysis of $\mathrm{X} 1, \mathrm{X} 2$, and $\mathrm{X} 3$ on student achievement can be shown in table 3 and table 4.

TABLE III. SUMMARY MODEL PATH ANALYSIS

\begin{tabular}{|l|c|l|l|l|}
\hline Model & R & $\begin{array}{c}\text { R } \\
\text { Square }\end{array}$ & $\begin{array}{c}\text { Adjusted R } \\
\text { Square }\end{array}$ & $\begin{array}{c}\text { Std. Error of the } \\
\text { Estimate }\end{array}$ \\
\hline 1 & $.883^{\text {a }}$ & .779 & .613 & 9.41906 \\
\hline \multicolumn{4}{|c}{ a. Predictors: (Constant), PCK (X2), SE (X3), CK (X1). }
\end{tabular}

TABLE IV. COEFFICIENTS ${ }^{\mathrm{A}}$ PATH ANALYSIS

\begin{tabular}{|c|c|c|c|c|c|c|}
\hline \multirow{2}{*}{\multicolumn{2}{|c|}{ Model }} & \multicolumn{2}{|c|}{$\begin{array}{l}\text { Unstandardized } \\
\text { Coefficients }\end{array}$} & \multirow{2}{*}{$\begin{array}{c}\begin{array}{c}\text { Standar } \\
\text { dized } \\
\text { Coefficie } \\
\text { nts }\end{array} \\
\text { Beta } \\
\end{array}$} & \multirow[t]{2}{*}{$t$} & \multirow[t]{2}{*}{ Sig. } \\
\hline & & $B$ & Std. Error & & & \\
\hline \multirow[t]{4}{*}{1} & $\begin{array}{l}\text { (Const } \\
\text { ant) }\end{array}$ & -107577 & 81.457 & & -1.321 & 257 \\
\hline & $\begin{array}{l}\text { CK } \\
(\mathrm{X} 1)\end{array}$ & 2.484 & .807 & 2.282 & 3.077 & .037 \\
\hline & $\begin{array}{l}\text { SE } \\
(\mathrm{X} 3)\end{array}$ & 2.241 & 1.129 & 1.263 & 1.985 & .118 \\
\hline & $\begin{array}{l}\text { PCK } \\
\text { (X2) }\end{array}$ & -2.855 & .968 & -2.638 & -2.951 & .042 \\
\hline
\end{tabular}

a. Dependent Variable: achievement (Y).

Based on table 4 the significance value for $\mathrm{X} 1$ is 0.037 (smaller than 0.05), the significance value for $\mathrm{X} 3$ is 0.118 (greater than 0.05) and the significance value for X2 is 0.042 (smaller than 0.05). This means that those who have a relationship with learning achievement are CK, and PCK. Because it was re-analysed without involving X3. Summary of the results of the analysis are in table 5 and table 6 .

\begin{tabular}{|c|c|c|c|c|}
\hline Model & R & $\begin{array}{c}\text { R } \\
\text { Square }\end{array}$ & $\begin{array}{c}\text { Adjusted R } \\
\text { Square }\end{array}$ & $\begin{array}{c}\text { Std. Error of the } \\
\text { Estimate }\end{array}$ \\
\hline 1 & $.749^{\text {a }}$ & .561 & .385 & 11.86864 \\
\hline \multicolumn{4}{|c}{ a. Predictors: (Constant), PCK (X2), CK (X1) }
\end{tabular}

TABLE VI. COEFFICIENTS ${ }^{\mathrm{A}}$ PATH ANALYSIS

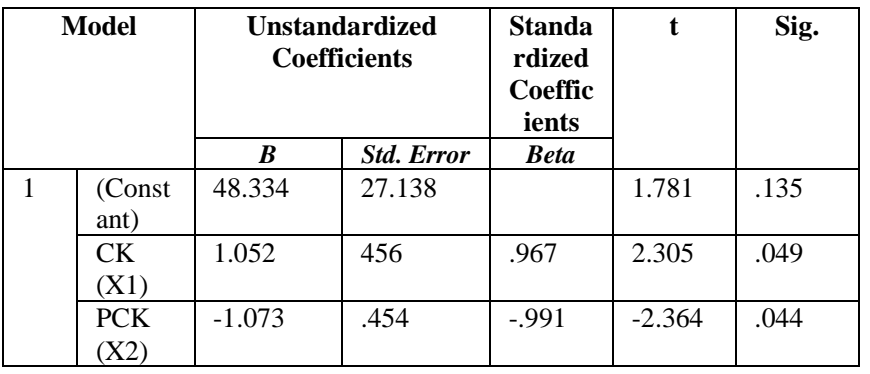

a. Dependent Variable: achievement (Y)

Based on table 6 above, the significance value of $\mathrm{X} 1$ is 0.049 , and the X2 significance value is 0.044 , both of which are smaller than 0.05 . It has meaning that the significance level of $5 \%$, then $\mathrm{X} 1$ and $\mathrm{X} 2$ a direct effect on $\mathrm{Y}$. The Summary Model obtained R2 of 0.561, this means that there are $56.1 \%$ student achievement is influenced by CK and PCK, while the remaining $43.9 \%$ is influenced by other factors, outside the research.

\section{CONCLUSIONS AND RECOMMENDATIONS}

The teacher is one of the factors that influence student achievement. Content knowledge, pedagogic content knowledge, and self-efficacy owned by teachers will characterize the performance of teachers. $\mathrm{CK}$ is the teacher's understanding of learning and knowledge material with other material related to what is taught. PCK teacher deals with an understanding of the concept of errors made by the students, understand the reasons students do misconceptions, create student solutions to change students' misconceptions, and ask the right questions to correct student misconceptions. The teacher's self-efficacy (SE) is the teacher's self-confidence in his ability to plan, implement, and assess learning in order to achieve the expected competencies. Based on empirical data and a significance level of $5 \%$, it can be seen that there is no significant relationship between $\mathrm{CK}$ and PCK, SE and student achievement. However, there is a direct relationship between CK and student learning achievement and indirect CK through PCK to learning achievement with the contribution of $\mathrm{CK}$ and PCK to learning achievement is $56.1 \%$. Based on these findings it is recommended to continuously improve $\mathrm{CK}$ and PCK for teachers because they have a direct or indirect impact on student achievement.

\section{ACKNOWLEDGMENT}

Thank you to the Rector of Universitas Pendidikan Ganesha for the financial support provided so that this research can be carried out. 
[11] K. Daehler and M. Shinohara, "A complete circuit is a complete circle: Exploring the potential of case materials and methods to develop teachers' content knowledge and pedagogical content knowledge of science", Research in Science Education, p 267-288. 2001.

[1] E.B. Turnuklu, S. Yesildere, "The Pedagogical Content Knowledge In Mathematics: Preservice Primary Mathematics Teachers' Perspectives In Turkey". IUMPST, p 1-13. 2007.

[2] M. Peker, "Mathematics teaching anxiety and self-efficacy beliefs toward mathematics teaching: A path analysis". Educational Research and Reviews. p 97-104. 2016

[3] L. Etheridge, "Mathematics Anxiety and Mathematics Self Efficacy as Predictors of Mathematics Teaching Self Efficacy". Dissertation. Auburn, Alabama, 2016

[4] M. Gulistan, M. Athar Hussain and M. Mushtaq, "Relationship between Mathematics Teachers Self Efficacy and Students Academic Achievement at Secondary Level". Bulletin of Education and Research December. p 171-182. 2017.

[5] X. Liu and H. Koirala, "The Effect of Mathematics Self-Efficacy on Mathematics Achievement of High School Students". NERA Conference $\quad$ Proceedings $2009 . \quad$ Paper 30. http://digitalcommons.uconn.edu/nera_2009/30 (Retrieved on December 28, 2016), 2009

[6] N.L.M. Dwijayanti, I.G.P. Suharta, "Bruner's Cognitive Stages and Their Effects on the Understanding of Fraction Concept". IRJEIS. p 3341. 2017.

[7] E. Fennema and M. Franke, Teachers' knowledge and its impact in: D.A. Grouws (Ed) Handbook of Research on Mathematics Teaching and Learning (New York: Macmillan Publishing), 1992.

[8] D.L. Ball and M.H. Thames, "Content Knowledge for Teaching. What Makes It Special?" Journal of Teacher Education. 2008, p 389-407

[9] P.L. Grossman, The making of a teacher: Teacher knowledge and teacher education. New York: Teachers College Press, 1990.

[10] Jones and J. Moreland, "Enhancing practicing primary school teachers' pedagogical content knowledge in technology", International Journal of Technology and Design Education. p 121-140. 2004.
[12] S. An, G. Kulm, and Z. Wu, "The pedagogical content knowledge of middle school, mathematics teachers in China and the U.S.", Journal of Mathematics Teacher Education, p145-172. 2004.

[13] A. McDuffy, "Mathematics teaching as a deliberate practice: An Investigation of elementary pre-service teachers' reflective thinking during student teaching", Journal of Mathematics Teacher Education, $\mathrm{p}$ 33-61. 2004.

[14] K. Stacey, S. Helme, V. Steinle, A. Baturo, K. Irwin, J. Bana, "Preservice teachers' knowledge of difficulties in decimal numeration", Journal of Mathematics Teacher Education, p 205-225. 2001.

[15] V. Sánchez and S. Llinares, "Four student teachers' pedagogical reasoning on functions", Journal of Mathematics Teacher Education, 525. 2003.

[16] Bandura. Self Efficacy in Changing Society. USA :Stanford University, 1997.

[17] T.R. Guskey and P.D. Passaro, "Teacher Efficacy: A study of Construct Dimensions". American Educational Research Journal, p 627-643. 1994.

[18] M. Tschannen-Moran and A. Woolfolk Hoy, "Teacher Efficacy: Capturing an Elusive Construct". Teaching and Teacher Education, p 783-805. 2001.

[19] P.F. Campbell, M. Nishio, T.M. Smith, L.M. Clark, D.L. Conant, A.H. Rust, J.N. DePiper, T.J. Frank, M.J. Griffin, Y. Choi, “The Relationship Between Teachers' Mathematical Content and Pedagogical Knowledge, Teachers' Perceptions, and Student Achievement”. JRME. p419-459. 2014.

[20] L.S. Sulman, Those Who Understand: KnowledgGer owth in Teaching. American Educational Research Association. p4-14. 1986.

[21] Ministry of Education and Culture (Ministry of Education and Culture), Class VIII Mathematics Teacher's Book on Mathematics. Jakarta: Ministry of Education and Culture, 2014 